\title{
Beetles (Insecta, Coleoptera) associated with pig carcasses exposed in a Caatinga area, Northeastern Brazil
}

\author{
Santos, WE. ${ }^{a *}$, Alves, $A C F^{a}{ }^{a}$ and Creão-Duarte, AJ. ${ }^{a}$ \\ ${ }^{a}$ Laboratório de Entomologia, Programa de Pós-Graduação em Ciências Biológicas (Zoologia), \\ Departamento de Sistemática e Ecologia, Universidade Federal da Paraíba - UFPB, \\ Cidade Universitária, CEP 58059-900, João Pessoa, PB, Brazil \\ *e-mail: well-bio@hotmail.com
}

Received: March 11, 2013 - Accepted: May 15, 2013 - Distributed: August 31, 2014

\begin{abstract}
The species richness, abundance and seasonality of Coleoptera fauna associated with pig carcasses exposed in a Caatinga area were examined. Tray, pitfall and modified Shannon traps were settled together to collect these insects during two seasons (dry and rainy). 4,851 beetles were collected, belonging to 19 families and 88 species. Staphylinidae $(2,184)$ and Histeridae $(1,264)$ were the most abundant families and accounted for $71.1 \%$ of the specimens collected. Scarabaeidae (15) showed the highest species richness. The most abundant species were Atheta iheringi Bernhauer, 1908 (Staphylinidae) (1,685), Euspilotus sp. (Histeridae) (461), Stelidota geminata (Say, 1825) (Nitidulidae) (394), Xerosaprinus diptychus (Marseul, 1855) (Histeridae) (331) and Dermestes maculatus De Geer, 1774 (Dermestidae). Amongst these species, X. diptychus showed to be strongly influenced by seasonality, since $96.1 \%$ of the specimens were collected during the dry season.
\end{abstract}

Keywords: animal decomposition, biodiversity, forensic entomology, necrophagous insects, seasonality.

\section{Coleópteros (Insecta, Coleoptera) associados a carcaças de suínos em Caatinga, Nordeste do Brasil}

\begin{abstract}
Resumo
A riqueza, abundância e sazonalidade da coleopterofauna associada a carcaças de suínos expostas em uma área de Caatinga foram examinadas. Para captura desses insetos foram utilizadas armadilhas do tipo bandeja, pitfall e Shannon modificada, durante duas estações (seca e chuvosa). 4.851 coleópteros foram coletados, pertencentes a 19 famílias e 88 espécies. Staphylinidae (2.184) e Histeridae (1.264) foram as famílias mais abundantes e somaram $71,1 \%$ dos espécimes coletados. Scarabaeidae (15) apresentou a maior riqueza. As espécies mais abundantes foram Atheta iheringi Bernhauer, 1908 (Staphylinidae) (1,685), Euspilotus sp. (Histeridae) (461), Stelidota geminata (Say, 1825) (Nitidulidae) (394), Xerosaprinus diptychus (Marseul, 1855) (Histeridae) (331) e Dermestes maculatus De Geer, 1774 (Dermestidae). Entre essas espécies, $X$. diptychus mostrou-se fortemente influenciada pela sazonalidade, uma vez que $96,1 \%$ dos espécimes foram coletados durante a estação seca.
\end{abstract}

Palavras-chave: decomposição animal, biodiversidade, entomologia forense, insetos necrófagos, sazonalidade.

\section{Introduction}

Insects are usually the first animals to locate a cadaver, attracted by the odours and gases released by it, and then start to use it as a resource for feeding, reproduction and larval development (Cornaby, 1974). This entomofauna attracts also another kind of fauna, consisting of predatory insects (Smith, 1986). The beetles belong to both ecological categories. Few species are effectively necrophagous, while most of them are predatory, but both categories can provide useful information from the forensic point of view, especially concerning to the estimation of the postmortem interval (PMI) (Catts and Goff, 1992; Santos et al. 2013).

In Brazil, important contributions to diversity, ecology and taxonomy of the fauna associated with carcasses have been made in the last two decades, but the majority of the studies have focussed on Diptera and are concentrated in the Southeast and South regions (Pujol-Luz et al., 2008). However, due to their succession pattern, Coleoptera are the most useful insects for the estimation of PMI when skeletonised corpses are found (Kulshrestha and Satpathy, 2001). In some cases, it is possible to estimate the PMI based on rates of development of some species (Arnaldos et al., 2004). Coleoptera can also be used to support the PMI estimate from Diptera data (Goff and Flynn, 1991).

Regional and seasonal studies are essential to identify specific cadaveric fauna, since each biome and season has its specific fauna because of particular environmental 
conditions (Mise et al., 2010; Rosa et al., 2011). The main objective was to analyse the diversity of the Coleoptera fauna associated with pig (Sus scrofa Linnaeus, 1758) carcasses, during the dry and wet seasons in Caatinga, a dry forest endemic to Brazil, whose insect fauna is poorly known (Vasconcellos et al., 2010; Creão-Duarte et al. 2013; Alves et al., 2014). Brief comments on the main families of forensic importance are also included, highlighting the richness, abundance, behaviour and ecological aspects of some species.

\section{Material and Methods}

The study was carried out during October 2010 (dry season) and February 2011 (rainy season) at the Private Reserve for the Environmental Inheritance Fazenda Almas (RPPN Fazenda Almas), in São José dos Codeiros, state of Paraíba, Brazil (7²8' 19' S, 36 53'40” W). The study area is located at an altitude of $650 \mathrm{~m}$ a.s.l. and $300 \mathrm{~km}$ away from the coast. The vegetation varies from open to dense arboreal Caatinga, with a strong deciduous characteristic during the dry season. The soil is sandy and arid and the topography is irregular, with inselbergs and rocky outcrops (Vasconcellos et al., 2010).

Two male pig carcasses, weighing around $15 \mathrm{~kg}$ each, were used in both seasons. The animals were killed with a single gunshot to the head. Each carcass was exposed in an iron cage to prevent interference of vertebrate scavengers. Underneath the cage there was a trap tray buried at ground level containing sawdust in order to collect actively the Coleoptera that take shelter under the carcasses. Four pitfall traps were settled around the cage, $1 \mathrm{~m}$ away from it, to passive capture. Each cage was also covered by a modified Shannon trap with a collector tube containing $70 \%$ alcohol at the apex (Alves et al., 2014). Coleoptera were collected daily in and from the traps.

The identification of the Coleoptera was done by experts and specific literature (Mazur, 2001; NavarreteHeredia et al., 2002; Almeida and Mise, 2009; Vaz-deMello et al., 2011; Aballay et al., 2013). All material used was incorporated into the Coleção Entomológica do Departamento de Sistemática e Ecologia at Universidade Federal da Paraíba (DSEC/UFPB).

\section{Results and Discussion}

A total of 4,851 adults belonging to 19 families and 88 species was collected (Table 1). Staphylinidae was the most abundant family with 2,184 individuals, followed by Histeridae (1,264), Nitidulidae (395), Dermestidae (333), Scarabaeidae (300), Cleridae (120), Carabidae (75) and Trogidae (75), amounting to $97.8 \%$ of the specimens.

Under similar conditions different results were obtained by Carvalho et al. (2000), in Campinas, state of São Paulo, whose decreasing order of abundance was Scarabaeidae, Histeridae, Silphidae and Staphylinidae. Mise et al. (2007), in Curitiba, State of Paraná, found Staphylinidae as the most abundant family, as in the present study, followed by Silphidae, Histeridae and Cleridae. Rosa et al. (2011), in areas of Cerrado, in Uberlândia, State of Minas Gerais, collected mainly Dermestidae, Histeridae, Cleridae and

Table 1. Absolute (n) and relative (\%) abundance, and species richness (S) of Coleoptera families associated to pig carcasses during dry and rainy seasons in a Caatinga area, state of Paraíba, Brazil.

\begin{tabular}{lccccccccc}
\hline \multirow{2}{*}{ Family } & \multicolumn{3}{c}{ Dry season } & \multicolumn{3}{c}{ Rainy season } & \multicolumn{3}{c}{ Total } \\
\cline { 2 - 10 } & $\mathbf{n}$ & $\mathbf{\%}$ & $\mathbf{S}$ & $\mathbf{n}$ & $\mathbf{\%}$ & $\mathbf{S}$ & $\mathbf{n}$ & $\mathbf{\%}$ & $\mathbf{S}$ \\
\hline Staphylinidae & 292 & 13.4 & 6 & 1,892 & 86.6 & 13 & 2,184 & 45.02 & 13 \\
Histeridae & 433 & 34.3 & 4 & 831 & 65.7 & 13 & 1,264 & 26.06 & 13 \\
Nitidulidae & 312 & 79.0 & 1 & 83 & 21.0 & 2 & 395 & 8.14 & 2 \\
Dermestidae & 229 & 68.8 & 1 & 104 & 31.2 & 2 & 333 & 6.86 & 2 \\
Scarabaeidae & 9 & 3 & 4 & 291 & 97 & 14 & 300 & 6.18 & 15 \\
Cleridae & 74 & 61.7 & 1 & 46 & 38.3 & 1 & 120 & 2.47 & 1 \\
Carabidae & 2 & 2.7 & 2 & 73 & 97.3 & 6 & 75 & 1.55 & 7 \\
Trogidae & 13 & 17.3 & 1 & 62 & 82.7 & 1 & 75 & 1.55 & 1 \\
Tenebrionidae & 35 & 94.6 & 6 & 2 & 5.4 & 1 & 37 & 0.76 & 7 \\
Curculionidae & 5 & 23.8 & 3 & 16 & 76.2 & 7 & 21 & 0.43 & 10 \\
Chrysomelidae & 3 & 16.7 & 2 & 15 & 83.3 & 6 & 18 & 0.37 & 8 \\
Elateridae & 8 & 100 & 2 & - & - & - & 8 & 0.16 & 2 \\
Anobiidae & - & - & - & 7 & 100 & 1 & 7 & 0.14 & 1 \\
Erotylidae & 3 & 75 & 1 & 1 & 25 & 1 & 4 & 0.08 & 1 \\
Hydrophilidae & 3 & 100 & 1 & - & - & - & 3 & 0.06 & 1 \\
Bostrichidae & - & - & - & 3 & 100 & 1 & 3 & 0.06 & 1 \\
Mordellidae & - & - & - & 2 & 100 & 1 & 2 & 0.04 \\
Melyridae & - & - & - & 1 & 100 & 1 & 1 & 0.02 \\
Ptiliidae & - & - & - & 1 & 100 & 1 & 1 & 0.02 & 1 \\
Total & 1,421 & 29.3 & 35 & 3,430 & 70.7 & 72 & 4,851 & 100 & 88 \\
\hline & & & & & & & & 1 \\
\end{tabular}


Staphylinidae. These divergent results highlight the importance of local studies for forensic practice in Brazil.

High species richness of beetles associated to carcasses has been registered in the Neotropical region: 62 and 113 species were mentioned respectively by Luederwaldt (1911) and Pessôa and Lane (1941) in São Paulo and neighbourhood; 112 species were collected by Mise et al. (2007) in Curitiba, state of Paraná; and 41 species were found by Mise et al. (2010) in Manaus, State of Amazonas. These data demonstrate the importance of Coleoptera when sampling strategies do not neglect this taxonomic group.

Smith (1986) considered as Coleoptera families with forensic importance: Carabidae, Hydrophilidae, Silphidae, Leiodidae, Staphylinidae, Histeridae, Cleridae, Anthicidae, Dermestidae, Nitidulidae, Rhizophagidae, Ptinidae, Tenebrionidae, Scarabaeidae, Geotrupidae and Trogidae. Ten of these families were found in the present study and represented $98.7 \%$ of the specimens collected (Table 2).

Amongst the collected species, Pterostichus sp., Eremosaprinus sp., Ateuchus carbonarius (Harold, 1868), Canthidium manni Arrow, 1913, Coprophanaeus pertyi (Olsoufieff, 1924), Deltochilum verruciferum Felsche, 1911, Dichotomius geminatus (Arrow, 1913), Acylophorus sp., Philonthus figulus Erichson, 1840 and Tribolium sp. are reported for the first time associated to carcasses in the Neotropical region.

The most abundant beetles collected, with number of individuals greater than $1 \%$ of the total, were represented by 17 species: Atheta iheringi Bernhauer, $1908(1,685)$, Euspilotus sp. (461), S. geminata (394), Xerosaprinus diptychus (Marseul, 1855) (331), Dermestes maculatus De Geer, 1774 (330), Philonthus sp. 2 (294), Euspilotus azureus (Sahlberg, 1823) (188), A. carbonarius (129), Necrobia rufipes (De Geer, 1775) (120), Phelister sp. (114), Aleochara bonariensis Lynch, 1884 (102), Hister punctifer Paykull, 1811 (82), Omorgus suberosus Fabricius, 1775 (75), Omalodes foveola Erichson, 1834 (67), Loxandrus sp. (65), Belonuchus sp. 2 (48) and C. manni (47) (Table 2). These species totaled together $93.1 \%$ of all beetles collected. Future specific studies, mainly about succession pattern, life cicle and diet, are required for a better understanding of the relationship of these species with carcasses and thus establish its forensic importance.

Rove beetles (Staphylinidae) are common on carcasses because they are predators of larvae of other insects, with a preference for fly larvae (Navarrete-Heredia et al., 2002; Byrd and Castner, 2010). In addition, larvae of some species of Aleochara are ectoparasites of fly pupae (Smith 1986). Staphylinidae was the most abundant family in the study, with 2,184 specimens, mainly represented by $A$. iheringi $(1,685)$ and species of Philonthus (326). Most of the Staphylinidade were collected in the rainy season $(86.6 \%)$, which also showed higher species richness (13) (Table 2).

Mise et al. (2007) highlighted Staphylinidae as the most abundant family, as in this study, with 29 species and 2,450 individuals captured. In many studies conducted in the Neotropical region, due to lack of specialists, the identification of these beetles is done only until genus.
However, there seems to be a similarity of the composition of the Staphylinidae fauna among different regions in Brazil, mainly represented by Aleochara and Philonthus (Souza and Linhares, 1997; Mise et al., 2007; Mise et al., 2010; Rosa et al., 2011; Silva and Santos, 2012). In other countries, several different genera were recorded occurring on carcasses (Wolff et al., 2001; Battán Horenstein and Linhares, 2011; Aballay et al., 2012).

The great abundance of the family Histeridae is mainly due to the fact that their species are predators of larvae of flies, food resource widely available on carcasses (Smith, 1986; Byrd and Castner, 2010). Histeride was the second most abundant family in this study, represented mainly by species of Euspilotus (649), collected mostly during the rainy season $(92.4 \%)$, and $X$. diptychus (331), in the dry season $(96.1 \%)$ (Table 2).

Aballay et al. (2012) found X. diptychus and five species of Euspilotus on pig carcasses in a different kind of arid environment, in San Juan, Argentina. The other genera and species of Histeride collected are commonly found on carcasses throughout the Neotropical region (Souza and Linhares, 1997; Carvalho et al., 2000; Wolff et al., 2001; Mise et al., 2007, 2010; Battán Horenstein and Linhares, 2011; Silva and Santos, 2012; Aballay et al., 2013).

Larvae and adults of Nitidulidae are generally saprophagous or xylophagous, feeding on decaying or dead wood. However, some species are exclusively phytophagous or mycophagous and others occur on carcasses or are predators (Smith, 1986; Marinoni et al., 2001). Nitidulidae was the third family in order of abundance and was almost totally represented by $S$. geminata with 394 individuals collected, mostly during the dry season (79.2\%) (Table 2).

According to Ewing and Cline (2005), S. geminata is commonly found in leaf litter and in decaying fruits and wood. The species probably plays a facultative necrophagous role in the carcasses, although it has not been observed feeding directly from it. Future studies about the biology of the species need to be done to elucidate this issue. Payne and King (1970), in South Carolina, USA, found nine species of Nitidulidae during advanced stages of decomposition of pigs together with Dermestidae. However, records of the family on carcasses are rare in the Neotropical region (Wolff et al., 2001; Mise et al., 2007; Battán Horenstein and Linhares, 2011; Silva and Santos, 2012).

Many larder beetles (Dermestidae) species, especially those of the genus Dermestes, are of considerable forensic importance. In cases in which the mummification of the body takes place, even indoors, these beetles can accelerate the skeletonisation process (Voigt, 1965; Schroeder et al., 2002) and, even so, adults and larvae can be found associated with the remains years after death (Byrd and Castner, 2010). In the present study, three individuals of Dermestes haemorrhoidalis Küster, 1852 and 330 individuals of D. maculatus were collected. The last one is the most forensically important Coleoptera species in the Neotropical region and was more abundant in the dry season (69.4\%) (Table 2). 
Table 2. Absolute (n) and relative (\%) abundance of Coleoptera species of forensic importance associated to pig carcasses during dry and rainy seasons in a Caatinga area, State of Paraíba, Brazil.

\begin{tabular}{|c|c|c|c|c|c|c|c|}
\hline \multirow{2}{*}{ Family } & \multirow{2}{*}{ Species } & \multicolumn{2}{|c|}{ Dry season } & \multicolumn{2}{|c|}{ Rainy season } & \multicolumn{2}{|c|}{ Total } \\
\hline & & $\mathbf{n}$ & $\%$ & $\mathbf{n}$ & $\%$ & n & $\%$ \\
\hline \multirow[t]{3}{*}{ Carabidae } & Loxandrus sp. & 1 & 1.5 & 64 & 98.5 & 65 & 1.36 \\
\hline & Pterostichus sp. & - & - & 4 & 100 & 4 & 0.08 \\
\hline & Carabidae spp. (5) & 1 & 16.7 & 5 & 83.3 & 6 & 0.13 \\
\hline Cleridae & Necrobia rufipes (De Geer, 1775) & 74 & 61.7 & 46 & 38.3 & 120 & 2.51 \\
\hline \multirow[t]{2}{*}{ Dermestidae } & Dermestes maculatus De Geer, 1774 & 229 & 69.4 & 101 & 30.6 & 330 & 6.90 \\
\hline & Dermestes haemorrhoidalis Küster, 1852 & - & - & 3 & 100 & 3 & 0.06 \\
\hline \multirow[t]{9}{*}{ Histeridae } & Eremosaprinus sp. & 2 & 50 & 2 & 50 & 4 & 0.08 \\
\hline & Euspilotus azureus (Sahlberg, 1823) & - & - & 188 & 100 & 188 & 3.93 \\
\hline & Euspilotus sp. & 49 & 10.6 & 412 & 89.4 & 461 & 9.63 \\
\hline & Hister punctifer Paykull, 1811 & - & - & 82 & 100 & 82 & 1.71 \\
\hline & Hololepta reichii Marseul, 1853 & - & - & 6 & 100 & 6 & 0.13 \\
\hline & Omalodes foveola Erichson, 1834 & - & - & 67 & 100 & 67 & 1.40 \\
\hline & Phelister sp. & 64 & 56.1 & 50 & 43.9 & 114 & 2.38 \\
\hline & Xerosaprinus diptychus (Marseul, 1855) & 318 & 96.1 & 13 & 3.9 & 331 & 6.92 \\
\hline & Histeridae spp. (5) & - & - & 11 & 100 & 11 & 0.23 \\
\hline Hydrophilidae & Hydrophilidae sp. & 3 & 100 & - & - & 3 & 0.06 \\
\hline \multirow[t]{2}{*}{ Nitidulidae } & Stelidota geminata (Say, 1825) & 312 & 79.2 & 82 & 20.8 & 394 & 8.23 \\
\hline & Nitidulidae sp. & - & - & 1 & 100 & 1 & 0.02 \\
\hline \multirow[t]{15}{*}{ Scarabaeidae } & Ataenius sp. & 2 & 50 & 2 & 50 & 4 & 0.08 \\
\hline & Ateuchus carbonarius (Harold, 1868) & 2 & 1.6 & 127 & 98.4 & 129 & 2.70 \\
\hline & Canthidium manni Arrow, 1913 & - & - & 47 & 100 & 47 & 0.98 \\
\hline & Canthon sp. & - & - & 1 & 100 & 1 & 0.02 \\
\hline & Coprophanaeus pertyi (Olsoufieff, 1924) & - & - & 2 & 100 & 2 & 0.04 \\
\hline & Deltochillum verruciferum Felsche, 1911 & - & - & 13 & 100 & 13 & 0.27 \\
\hline & Dichotomius geminatus (Arrow, 1913) & - & - & 25 & 100 & 25 & 0.52 \\
\hline & Dichotomius nisus (Olivier, 1789) & - & - & 9 & 100 & 9 & 0.19 \\
\hline & Ontherus digitatus Harold, 1868 & 1 & 100 & - & - & 1 & 0.02 \\
\hline & Onthophagus hirculus Mannerhein, 1829 & - & - & 22 & 100 & 22 & 0.46 \\
\hline & Trichillum sp. & - & - & 27 & 100 & 27 & 0.56 \\
\hline & Uroxys sp. & 4 & 36.4 & 7 & 63.6 & 11 & 0.23 \\
\hline & Aphodiinae sp. 1 & - & - & 3 & 100 & 3 & 0.06 \\
\hline & Aphodiinae sp. 2 & - & - & 5 & 100 & 5 & 0.10 \\
\hline & Melolonthinae sp. & - & - & 1 & 100 & 1 & 0.02 \\
\hline \multirow[t]{12}{*}{ Staphylinidae } & Acylophorus sp. & - & - & 1 & 100 & 1 & 0.02 \\
\hline & Aleochara bonariensis Lynch, 1884 & 8 & 7.8 & 94 & 92.2 & 102 & 2.13 \\
\hline & Atheta iheringi Bernhauer, 1908 & 177 & 10.5 & 1,508 & 89.5 & 1,685 & 35.21 \\
\hline & Belonuchus sp. 1 & - & - & 2 & 100 & 2 & 0.04 \\
\hline & Belonuchus sp. 2 & 23 & 47.9 & 25 & 52.1 & 48 & 1.00 \\
\hline & Heterothops sp. 1 & 1 & 9.1 & 10 & 90.9 & 11 & 0.23 \\
\hline & Heterothops sp. 2 & - & - & 4 & 100 & 4 & 0.08 \\
\hline & Philonthus figulus Erichson, 1840 & 3 & 13.6 & 19 & 86.4 & 22 & 0.46 \\
\hline & Philonthus sp. 1 & - & - & 10 & 100 & 10 & 0.21 \\
\hline & Philonthus sp. 2 & 80 & 27.2 & 214 & 72.8 & 294 & 6.14 \\
\hline & Xenopygus analis (Erichson, 1840) & - & - & 2 & 100 & 2 & 0.04 \\
\hline & Staphylinidae spp. (2) & - & - & 3 & 100 & 3 & 0.06 \\
\hline \multirow[t]{4}{*}{ Tenebrionidae } & Tribolium sp. 1 & 13 & 100 & - & - & 13 & 0.27 \\
\hline & Tribolium sp. 2 & 8 & 100 & - & - & 8 & 0.17 \\
\hline & Bolitophagini sp. & 11 & 100 & - & - & 11 & 0.23 \\
\hline & Tenebrionidae spp. (4) & 3 & 60 & 2 & 40 & 5 & 0.10 \\
\hline Trogidae & Omorgus suberosus Fabricius, 1775 & 13 & 17.3 & 62 & 82.7 & 75 & 1.57 \\
\hline Total & & 1,402 & 29.3 & 3,384 & 70.7 & 4,786 & 100 \\
\hline
\end{tabular}


Several authors have reported the presence of adults and larvae of $D$. maculatus on carcasses and corpses in Brazil (Souza and Linhares, 1997; Carvalho et al., 2000; Carvalho et al., 2004; Mise et al., 2007; Rosa et al., 2011) and the rest of the Neotropical region (Iannacone, 2003; Velásquez, 2008; Valdes-Perezgasga et al., 2010; Battán Horenstein and Linhares, 2011; Aballay et al., 2012). Mise et al. (2007), in an Araucaria forest fragment, found only 22 specimens of $D$. maculatus, while Rosa et al. (2011), in an area of Cerrado, collected 4,874 individuals, the majority in the dry season $(94.6 \%)$, the same as in the present study. Despite differences between sampling methods, it seems to be clear the divergence in the abundance status of D. maculatus among different habitats, with a preference for drier regions.

With over 19,000 species described, Scarabaeidae vary greatly in biology, ecology and behaviour (Byrd and Castner, 2010). The members of this family are mainly detritivorous, with larvae feeding on dung or pieces of decomposing carcasses (Smith, 1986; Marinoni et al., 2001). Many species dig oviposition chambers and tunnels under or near the carcasses, where pieces of the carcass are deposited to feed the larvae, which can cause postmortem movement of the bodies (Ururahy-Rodrigues et al., 2008). In the present study, this family was the fifth most abundant, with 300 individuals, mostly present in the rainy season (97\%). Fifteen species were collected, especially of the subfamily Scarabaeinae, mainly represented by A. carbonarius (43.0\%) and C. manni (15.7\%) (Table 2), which were very abundant in a study carried out by Hernández (2007) in the same study area.

In Brazil, the studies by Luederwaldt (1911) and Pessôa and Lane (1941) about Scarabaeidae associated with carcasses of several animals in São Paulo and surrounding cities are historical references. Together, these authors recorded 124 species, most of them belonging to the genera Canthidium, Canthon, Coprophanaeus, Deltochilum and Phanaeus.

Most of Cleridae are predators of larvae of flies and other beetles, but the genus Necrobia has necrophagous habit, with a preference for carcasses and corpses in dry stages of decomposition (Payne and King, 1970; Arnaldos et al., 2004). This family was the sixth in order of abundance and represented only by $N$. rufipes, with 120 specimens collected and showing preference for the dry season (61.7\%) (Table 2).

Rosa et al. (2011) collected that species in great abundance $(2,321)$ in an area of Cerrado, most of them in the dry season as well (94.1\%). Adults and larvae of $N$. rufipes are widely found on carcasses and corpses in Brazil (Luederwaldt, 1911; Souza and Linhares, 1997; Carvalho et al., 2000, 2004; Mise et al., 2007; Silva and Santos, 2012) and elsewhere in the Neotropical region (Wolff et al., 2001; Iannacone, 2003; ValdesPerezgasga et al., 2010; Battán Horenstein and Linhares, 2011; Aballay et al., 2012).

The diversity of Coleoptera fauna was different from other studies carried out in the Neotropical region, which may be a result not only from different environments, but also the capture method adopted. Ten species were recorded for the first time associated with carcasses in the Neotropical region. Populations of Staphylinidae and Histeridae, the most abundant families, can be considered as affected by seasonality, with only $13.4 \%$ and $34.2 \%$ of the specimens collected, respectively, in the dry season. Amongst the most collected species, $X$. diptychus showed to be strongly influenced by the dry season, since $96.1 \%$ of the specimens were collected during that period. A. iheringi, representing $34.7 \%$ of the total, was the most abundant species. Future studies are required to confirm the role of these beetles on carcasses and its possible forensic potential to Caatinga. In addition, the exceptional Coleoptera fauna found reinforces the need of regional studies about the composition of insects associated with carcasses throughout Neotropical region.

\section{Acknowledgements}

The authors are thankful to Dr. Edilson Caron (UFPR), Dr. Daniel P. Moura (UFPR) and M.Sc. Carolina N. Liberal (UFPB) for their help with the identifications; Dr. Carla L. Bicho (UEPB), Dr. Patricia J. Thyssen (UFPel) and Dr. Rodrigo C. A. P. Farias (UFPB) for critical comments on the manuscript. Thanks are also due to the "Conselho Nacional de Desenvolvimento Científico e Tecnológico" (CNPq) and the "Coordenação de Aperfeiçoamento de Pessoal de Nível Superior" (CAPES) for providing scholarships to A. C. F. Alves and W. E. Santos.

\section{References}

ABALLAY, FH., ARRIAGADA, G., FLORES, GE. and CENTENO, ND., 2013. An illustrated key to and diagnoses of the species of Histeridae (Coleoptera) associated with decaying carcasses in Argentina. ZooKeys, vol. 261, no. 261, p. 61-84. http://dx.doi. org/10.3897/zookeys.261.4226. PMid:23653510

ABALLAY, FH., MURUA, AF., ACOSTA, JC. and CENTENO, ND., 2012. Succession of carrion fauna in the arid region of San Juan Province, Argentina and its forensic relevance. Neotropical Entomology, vol. 41, no. 1, p. 27-31. http://dx.doi.org/10.1007/ s13744-011-0005-9. PMid:23950006

ALMEIDA, LM. and MISE, KM., 2009. Diagnosis and key of the main families and species of South American Coleoptera of forensic importance. Revista Brasileira de Entomologia, vol. 53, no. 2, p. 227-244. http://dx.doi.org/10.1590/S0085-56262009000200006.

ALVES, ACF., SANTOS, WE., FARIAS, RCAP. and CREÃODUARTE, AJ., 2014. Blowflies (Diptera, Calliphoridae) associated with pig carcasses in a Caatinga area, Northeastern Brazil. Neotropical Entomology, vol. 43, no. 2, p. 122-126. http://dx.doi. org/10.1007/s13744-013-0195-4.

ARNALDOS, MI., SÁNCHEZ, F., ÁLVARES, P. and GARCÍA, MD., 2004. A forensic entomology case from the Southeastern Iberian Peninsula. Anil Aggrawal's Internet Journal of Forensic Medicine and Toxicology, vol. 5, p. 22-25.

BATTÁN HORENSTEIN, M. and LINHARES, AX., 2011. Seasonal composition and temporal succession of necrophagous 
and predator beetles on pig carrion in central Argentina. Medical and Veterinary Entomology, vol. 25, no. 4, p. 395-401. http:// dx.doi.org/10.1111/j.1365-2915.2011.00969.x. PMid:21762401

BYRD, JH. and CASTNER, JL., 2010. Insects of forensic importance. In BYRD, JH. and CASTNER, JL. (Eds.). Forensic entomology: the utility of arthropods in legal investigations. Boca Raton: CRC Press. p. 39-126.

CARVALHO, LM., THYSSEN, PJ., LINHARES, AX. and PALHARES, FAB., 2000. A checklist of arthropods associated with pig carrion and human corpses in southeastern Brazil. Memorias do Instituto Oswaldo Cruz, vol. 95, no. 1, p. 135-138. http:// dx.doi.org/10.1590/S0074-02762000000100023. PMid:10656720

CARVALHO, LML., THYSSEN, PJ., GOFF, ML. and LINHARES, AX., 2004. Observations on the succession patterns of necrophagous insects on a pig carcass in an urban area of Southeastern Brazil. Anil Aggrawal's Internet Journal of Forensic Medicine and Toxicology, vol. 5, p. 33-39.

CATTS, EP. and GOFF, ML., 1992. Forensic entomology in criminal investigations. Annual Review of Entomology, vol. 37, no. 1, p. 253-272. http://dx.doi.org/10.1146/annurev.en.37.010192.001345. PMid: 1539937

CORNABY, BW., 1974. Carrion reduction by animals in contrasting tropical habitats. Biotropica, vol. 6, no. 1, p. 51-63. http://dx.doi. org/10.2307/2989697.

CREÃO-DUARTE, AJ., ANJOS, UU. and SANTOS, WE., 2012. Diversidade de membracídeos (Hemiptera, Membracidae) e sobreposição de recursos tróficos em área do semi-árido. Iheringia Série Zoologia, vol. 102, no. 4, p. 453-458. http:// dx.doi.org/10.1590/S0073-47212012000400012.

EWING, CP. and CLINE, AR., 2005. Key to adventive sap beetles (Coleoptera: Nitidulidae) in Hawaii, with notes on records and habits. The Coleopterists Bulletin, vol. 59, no. 2, p. 167-183. http://dx.doi.org/10.1649/736.

GOFF, ML. and FLYNN, MM., 1991. Determination of postmortem interval by arthropod succession: a case study from the Hawaiian Islands. Journal of Forensic Sciences, vol. 36, no. 2, p. 607-614. PMid:2066736.

HERNÁNDEZ, MIM., 2007. Besouros escarabeíneos (Coleoptera: Scarabaeidae) da Caatinga paraibana, Brasil. Oecologia Brasiliensis, vol. 11, no. 03, p. 356-364. http://dx.doi.org/10.4257/ oeco.2007.1103.06.

IANNACONE, J., 2003. Artropofauna de importancia forense en un cadaver de cerdo en el Callao, Peru. Revista Brasileira de Zoologia, vol. 20, no. 1, p. 85-90. http://dx.doi.org/10.1590/ S0101-81752003000100010.

KULSHRESTHA, P. and SATPATHY, DK., 2001. Use of beetles in forensic entomology. Forensic Science International, vol. 120, no. 1-2, p. 15-17. http://dx.doi.org/10.1016/S0379-0738(01)004108.PMid: 11457603

LUEDERWALDT, G., 1911. Os insectos necrophagos paulistas. Revista do Museu Paulista, vol. 8, p. 414-433.

MARINONI, RC., GANHO, NG., MONNÉ, ML. and MERMUDES, JRM., 2001. Hábitos alimentares em Coleoptera (Insecta). Ribeirão Preto: Holos. 63 p.

MAZUR, S., 2001. Review of the Histeridae (Coleoptera) of México. Dugesiana, vol. 8, no. 2, p. 17-66.

MISE, KM., ALMEIDA, LM. and MOURA, MO., 2007. Levantamento da fauna de Coleoptera que habita a carcaça de Sus scrofa L., em Curitiba, Paraná. Revista Brasileira de Entomologia, vol. 51, no. 3, p. 358-368. http://dx.doi.org/10.1590/ S0085-56262007000300014.

MISE, KM., SOUZA, ASB., CAMPOS, CM., KEPPLER, RLF. and ALMEIDA, LM., 2010. Coleoptera associated with pig carcass exposed in a forest reserve, Manaus, Amazonas, Brazil. Biota Neotropica, vol. 10, no. 1, p. 321-324. http://dx.doi.org/10.1590/ S1676-06032010000100027.

NAVARRETE-HEREDIA, JL., NEWTON, AF., THAYER, MK., ASHE, JS. and HANDLER, DS., 2002. Guía ilustrada para los géneros de Staphylinidae (Coleoptera) de México. México: Universidad de Guadalajara/CONABIO. 401 p.

PAYNE, JA. and KING, EW., 1970. Coleoptera associated with pig carrion. Entomologist's Monthly Magazine, vol. 105, p. 224-232.

PESSÔA, SB. and LANE, F., 1941. Coleópteros de interesse médico-legal. Arquivos de Zoologia do Estado de São Paulo, vol. 2, p. 389-504.

PUJOL-LUZ, JR., ARANTES, LC. and CONSTANTINO, R., 2008. Cem anos da entomologia forense no Brasil (1908-2008). Revista Brasileira de Entomologia, vol. 52, no. 4, p. 485-492. http://dx.doi.org/10.1590/S0085-56262008000400001.

ROSA, TA., BABATA, MLY., SOUZA, CM., SOUSA, D., MELLO-PATIU, CA., VAZ-DE-MELLO, FZ. and MENDES, J., 2011. Arthropods associated with pig carrion in two vegetation profiles of Cerrado in the State of Minas Gerais, Brazil. Revista Brasileira de Entomologia, vol. 55, no. 3, p. 424-434. http:// dx.doi.org/10.1590/S0085-56262011005000045.

SANTOS, WE., ALVES, ACF., FARIAS, RCAP. and CREÃODUARTE, AJ., 2013. Ecological roles of Coleoptera associated with carcasses in Caatinga. EntomoBrasilis, vol. 6, no. 3, p. 248250. http://dx.doi.org/10.12741/ebrasilis.v6i3.325.

SCHROEDER, H., KLOTZBACH, H., OESTERHELWEG, L. and PÜSCHEL, K., 2002. Larder beetles (Coleoptera, Dermestidae) as an accelerating factor for decomposition of a human corpse. Forensic Science International, vol. 127, no. 3, p. 231-236. http:// dx.doi.org/10.1016/S0379-0738(02)00131-7. PMid:12175954

SMITH, KGV.,1986. A manual of forensic entomology. Ithaca: Cornell University Press. 205 p.

SILVA, RC. and SANTOS, WE., 2012. Fauna de Coleoptera associada a carcaças de coelhos expostas em uma área urbana no Sul do Brasil. EntomoBrasilis, vol. 5, no. 3, p. 185-189. http:// dx.doi.org/10.12741/ebrasilis.v5.i3.245.

SOUZA, AM. and LINHARES, AX., 1997. Diptera and Coleoptera of potential forensic importance in southeastern Brazil: relative abundance and seasonality. Medical and Veterinary Entomology, vol. 11, no. 1, p. 8-12. http://dx.doi.org/10.1111/j.1365-2915.1997. tb00284.x. PMid:9061672

URURAHY-RODRIGUES, A., RAFAEL, JA., WANDERLEY, RF., MARQUES, H. and PUJOL-LUZ, JR., 2008. Coprophanaeus lancifer (Linnaeus, 1767) (Coleoptera, Scarabaeidae) activity moves a man-size pig carcass: relevant data for forensic taphonomy. Forensic Science International, vol. 182, no. 1-3, p. e19-e22. http://dx.doi.org/10.1016/j.forsciint.2008.09.009. PMid:18990518

VALDES-PEREZGASGA, MT., SANCHEZ-RAMOS, FJ., GARCIA-MARTINEZ, O. and ANDERSON, GS., 2010. Arthropods of forensic importance on pig carrion in the Coahuilan semidesert, Mexico. Journal of Forensic Sciences, vol. 55, no. 4, p. 1098- 
1101. http://dx.doi.org/10.1111/j.1556-4029.2010.01381.x. PMid:20384924

VASCONCELLOS, A., ANDREAZZE, R., ALMEIDA, AM., ARAUJO, HFP., OLIVEIRA, ES. and OLIVEIRA, U., 2010. Seasonality of insects in a semi-arid Caatinga of Northeastern Brazil. Revista Brasileira de Entomologia, vol. 54, no. 3, p. 471-476. http://dx.doi.org/10.1590/S0085-56262010000300019.

VAZ-DE-MELLO, FZ., EDMONDS, WD., OCAMPO, FC. and SCHOOLMEESTERS, P., 2011. A multilingual key to the genera and subgenera of the subfamily Scarabaeinae of the New World (Coleoptera: Scarabaeidae). Zootaxa, vol. 2854, p. 1-73.
VELÁSQUEZ, Y., 2008. A checklist of arthropods associated with rat carrion in a montane locality of northern Venezuela. Forensic Science International, vol. 174, no. 1, p. 68-70. http:// dx.doi.org/10.1016/j.forsciint.2007.02.020. PMid:17386987

VOIGT, J., 1965. Specific postmortem changes produced by larder beetles. Journal of Forensic Medicine, vol. 12, p. 76-80. PMid:14328682.

WOLFF, M., URIBE, A., ORTIZ, A. and DUQUE, P., 2001. A preliminary study of forensic entomology in Medellín, Colombia. Forensic Science International, vol. 120, no. 1-2, p. 53-59. http:// dx.doi.org/10.1016/S0379-0738(01)00422-4. PMid:11457610 